\title{
A társadalmi-térbeli marginalizáció folyamatai a leszakadó vidéki térségekben
}

\section{The processes of socio-spatial marginalization in declining rural spaces}

\author{
NAGY ERIKA, TIMÁR JUDIT, NAGY GÁBOR, VELKEY GÁBOR
}

\begin{abstract}
NAGY Erika: tudományos főmunkatárs, MTA Közgazdaság- és Regionális Tudományi Kutatóközpont, Regionális Kutatások Intézete, Békéscsaba; nagye@rkk.hu

TIMÁR Judit: tudományos főmunkatárs, MTA Közgazdaság- és Regionális Tudományi Kutatóközpont, Regionális Kutatások Intézete, Békéscsaba; egyetemi docens, Debreceni Egyetem, Társadalomföldrajzi és Területfejlesztési Tanszék; timarj@rkk.hu

NAGY Gábor: tudományos főmunkatárs, MTA Közgazdaság- és Regionális Tudományi Kutatóközpont, Regionális Kutatások Intézete, Békéscsaba; egyetemi docens, Szegedi Tudományegyetem, Gazdaság- és Társadalomföldrajzi Tanszék; nagyg@rkk.hu VELKEY Gábor: tudományos munkatárs, MTA Közgazdaság- és Regionális Tudományi Kutatóközpont, Regionális Kutatások Intézete, Békéscsaba; egyetemi adjunktus, Szent István Egyetem, Gazdasági, Agrár- és Egészségtudományi Kar, Békéscsaba; velkeyg@rkk.hu
\end{abstract}

KULCSSZAVAK: marginalizáció, térbeli-társadalmi egyenlőtlenségek, függőség, szegénység, vidékkutatás, vidékföldrajz

ABSZTRAKT: Tanulmányunkban a szakmai diskurzusokban hátrányos helyzetűként megjelenített rurális térségekre fókuszálunk, azok marginalizációs folyamataira helyezve a hangsúlyt. Kiindulópontunk az, hogy a marginalitáskoncepció releváns értelmezési keret a „leszakadó” vidéki térségek társadalmi problémáinak megértéséhez. Az ilyen térségekben élő-működő, marginalizált helyzetű társadalmi csoportok - helyi lakosok és gazdasági szereplők - napi gyakorlatain keresztül vizsgáljuk azokat a mechanizmusokat, amelyekkel újratermelődnek a gazdasági-társadalmi hátrányok, a függőségek és a kirekesztettség. Írásunkban amellett érvelünk, hogy egyrészt a társadalmi marginalizálódás és a térbeli hátrányok halmozódása nem választhatók el egymástól; a vidéki terek marginalizálódása az ott élő-működő egyének, csoportok marginalizálódását is eredményezi, tovább rontva a térség helyzetét; másrészt hogy a vidéki terekben élő, marginalizált helyzetủ társadalmi csoportok maguk is arra kényszerülnek, hogy napi gyakorlataikkal fenntartsák/újratermeljék saját (marginalizált) helyzetüket a fennálló társadalmi-térbeli struktúrák keretei között. Következtetéseinket négy magyarországi a társadalmi és a térbeli marginalizáció számos összetevőjét hordozó - terepen végzett empirikus vizsgálatra alapozzuk.

Erika NAGY: senior research fellow, Institute for Regional Studies, Centre for Economic and Regional Studies, Hungarian Academy of Sciences, Békéscsaba; nagye@rkk.hu

Judit TIMÁR: senior research fellow, Institute for Regional Studies, Centre for Economic and

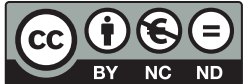


Regional Studies, Hungarian Academy of Sciences, Békéscsaba; associate professor, Department of Social Geography and Regional Development Planning, University of Debrecen; timarj@rkk.hu Gábor NAGY: senior research fellow, Institute for Regional Studies, Centre for Economic and Regional Studies, Hungarian Academy of Sciences, Békéscsaba; associate professor, Department of Economic and Social Geography, University of Szeged; nagyg@rkk.hu

Gábor VELKEY: research fellow, Institute for Regional Studies, Centre for Economic and Regional Studies, Hungarian Academy of Sciences, Békéscsaba; assistant professor, Faculty of Economics, Agriculture and Health Studies, Szent István University, Békéscsaba; velkeyg@rkk.hu

KEYWORDS: marginalization, socio-spatial inequalities, dependence, poverty, rural studies, rural geography, Hungary

ABSTRACT: Rurality has been associated with economic backwardness and social erosion in public discourses in Hungary since the early years of the transition, even though academic debates highlighted the diversity of historical trajectories and socio-cultural contexts of rural transformations. To contribute to a deeper, more nuanced understanding of major structural changes and their local consequences in rural spaces, we focus on marginalisation processes in four regions in Hungary that are labelled as 'declining' and 'backward' in political as well as academic discourses.

We consider marginalisation as a 'product' of changing social relations that become manifest in socio-spatial processes shaping all aspects of everyday life. This concept allows us to focus on daily practices of social groups (women, Roma, those who live with disability problems) and economic agents (entrepreneurs) living/operating in 'declining' rural spaces. In this way, we can explore the mechanisms that marginalise individuals, communities and spaces through various lenses, and reveal how marginality is 'lived' and responded to in various contexts. Our key arguments are the followings: 1 . The diverse processes of social marginalisation and the accumulation of backwardness in rural spaces are linked intimately, in fact, reinforce one another; thus, marginalisation should be considered as a spatial process that manifests itself at and through various scales - from neighbourhood to global level. 2. Marginalised groups and individuals living in backward rural spaces are compelled to adopt practices that reproduce their own disadvantages, dependencies (and often, exclusion) within the existing structuralinstitutional frameworks.

The analysis rests both on the transdisciplinary review of concepts and discourses over marginality and on social and economic structures in rural spaces. The empirical tier of the paper contains extensive field work in four socio-economic crisis-hit rural regions in Hungary (the micro-regions of Lengyeltóti, Mezókovácsháza, Sarkad and Sárospatak), completed in 2013. The empirical work based on qualitative methods (semi-structured interviews) by which we targeted marginalised social groups, local entrepreneurs and the institutions that shape - rather reinforce than counteract - everyday practices reproducing marginality.

\section{Bevezetés}

A magyarországi vidékkutatásokban nem alakult ki egyöntetű vélemény arról, hogy a rendszerváltozás utáni közbeszédben sokszínü vidékkép rajzolódik ki, vagy a vidék fogalma inkább a gazdasági válságjelenségekkel, a társadalmi konfliktusokkal, s általában véve, a leszakadó, hátrányos (térbeli) helyzettel mosódik össze (Csatári 2000; Csurgó 2007; Kovách 2007; Megyesi 2007). Ugyanakkor számos vizsgálat világított rá a rurális térségek differenciálódási folyamataira, s az azok hátterében álló, változó társadalmi viszonyokra, struktú- 
rákra - feltárva azok globális (a gazdaság „hálózatosodásában” és a vidéki térségek erősödő külső függőségében megragadható), az átmenet sajátos körülményeiben és a helyi történeti sajátosságokban gyökerező összetevőit (pl. Beluszky, Sikos 2007; Csurgó, Kovách, Megyesi 2009; Enyedi 1996). A vidék „leszakadó” (,elmaradott”) térségeiben halmozódó demográfiai, gazdasági, társadalmi problémákat a regionális kutatásokkal foglalkozók többsége a (makro)strukturális változások térbeli „eredményeként” értelmezte, s a térségi szereplők átalakuló hatalmi (piaci, állami-intézményi) struktúrákban elfoglalt, függö/alárendelt helyzetéből kiindulva magyarázta azokat (pl. Csatári 2005; Kovács 2010).

Jelen tanulmány keretei között mi is a szakmai diskurzusokban hátrányos helyzetüként megjelenített rurális térségekre fókuszálunk, azok marginalizációs folyamataira helyezve a hangsúlyt. Kiindulópontunk az, hogy a marginalitáskoncepció releváns értelmezési keret a „leszakadó” vidéki térségek társadalmi problémáinak megértéséhez. Az alábbiakban az ilyen térségekben élő-müködő, marginalizált helyzetü társadalmi csoportok - helyi lakosok és gazdasági szereplők - napi gyakorlatain keresztül vizsgáljuk azokat a mechanizmusokat, amelyekkel újratermelődnek a gazdasági-társadalmi hátrányok, a függőségek és a kirekesztettség. Írásunkban amellett érvelünk, hogy:

- a társadalmi marginalizálódás és a térbeli hátrányok halmozódása nem választható el egymástól; a vidéki terek marginalizálódása az ott élőműködő egyének, csoportok marginalizálódását is eredményezi, tovább rontva a térség helyzetét;

- a vidéki terekben élő, marginalizált helyzetü társadalmi csoportok maguk is arra kényszerülnek, hogy napi gyakorlataikkal fenntartsák/újratermeljék saját (marginalizált) helyzetüket a fennálló társadalmi-térbeli struktúrák keretei között.

Úgy véljük, koncepcionális megközelítésünkkel és empirikus eredményeinkkel hozzájárulhatunk egyrészt a magyarországi „vidéket” átformáló társadalmi-térbeli folyamatok mélyebb megismeréséhez, másrészt azokhoz a nemzetközi szakmai diskurzusokhoz, amelyek a marginalizáció térfolyamatként történő értelmezésére és ennek releváns térbeli kereteire (végső soron a cselekvő- vs. struktúraközpontú megközelítések „összebékítésére”) irányulnak (Berndt, Colini 2013; Schmidt 2007).

A tanulmány következő fejezetében az elemzés elméleti és módszertani kereteit vázoljuk, összekapcsolva a marginalitást a kapitalizmus egyenlőtlen hatalmi (társadalmi-térbeli) viszonyaiból indító koncepciókkal, valamint a társadalmi gyakorlatokat - a marginalitás „megélését” és az arra adott válaszokat - középpontba állító, tágabb (kulturális, etnikai, társadalmi nemek stb. szerinti) kontextusban vizsgáló megközelítéssel. A harmadik fejezetben a marginalitást újratermelő társadalmi gyakorlatokat a peremhelyzetet különböző módon/kontextusokban (nőként, romaként, fogyatékkal élőként) „megélők” nézőpontjából, élethelyzeteiken, stratégiáikon keresztül elemezzük. A negyedik fejezetben a helyi vállalkozók azon - többséget kitevő - csoportjaira koncentrá- 
lunk, amelyek gyenge piaci beágyazottságuk, erős függőségre épülő kapcsolatrendszereik és társadalmi környezetük kedvezőtlen folyamatai miatt kiszolgáltatottak, és üzleti gyakorlataikkal tovább erősítik térségük marginalizációs folyamatait. Az ötödik fejezetben - levonva a legfontosabb tanulságokat - arra igyekszünk rámutatni, hogy a vizsgált szereplők stratégiái és akciói hogyan termelnek (újra) régi-új függőségeket, erősítve/fenntartva a marginalizációs folyamatokat, amit az állami intézményi gyakorlatok tovább erősítenek.

\section{Elméleti-módszertani keretek: a marginalizáció mint a társadalmi-térbeli gyakorlatok eredője}

A piacgazdaság és a megváltozott politikai keretek között évtizedek óta makacsul újratermelődő egyenlőtlenségek - amelyek a regionális különbségek tartós fennmaradásában épp úgy megragadhatók, mint a város-vidék vagy főváros-vidék viszonyrendszerben - mind több kutatót ösztönöztek arra, hogy a térbeli egyenlőtlenségeket társadalmi konstrukcióként, „termékként” vizsgálják (pl. Halfacree 2007; Kovács 2010; Stenning, Smith, Rochovská, Światek 2011; Timár, Nagy 2012; Váradi 2005). Jelen tanulmányban a magyarországi vidéki terek átalakulásának, differenciálódásának folyamatait mi is hasonló felfogásban, a marginális helyzetek kialakulásának és újratermelödésének folyamataira, az azok hátterében álló mechanizmusokra koncentrálva tárgyaljuk. Mindezt a marginális helyzetü társadalmi csoportok és térségek nézőpontjából közelítjük.

A marginalizáció széles körben, többféle - egyre bővülő - jelentéstartalommal használt fogalom. Az utóbbi két évtizedben a marginalitást a nemzetközi szakirodalomban a legtöbben a társadalmi, gazdasági, politikai struktúrákban elfoglalt peremhelyzetként/kiszorítottságként, s az ebből fakadó hátrányként értelmezték (Berndt, Colini 2013). Ezek a társadalmi viszonyokból kiinduló értelmezések a neoliberális kapitalizmus korszakában a hatalomnélküliséget, az integráció és a részvétel hiányát - a munkaerő-piaci kiszolgáltatottságot, a társadalmi polarizációt, az állam csökkenő szerepét az egyenlőtlenségek mérséklésében, a lokális terekhez kötődő közösségek szétesését - tekintették/tekintik a marginalizálódás mozgatórugóinak (Berndt, Colini 2013; Wacquant 2011).

Aszimmetrikus hatalmi viszonyokból indulnak ki azok az érvelések is, amelyek a társadalmi diskurzusok - és az általuk formált piaci és állami intézményi gyakorlatok - marginalizáló szerepére hívják fel a figyelmet. A kirekesztettség az intézményi gyakorlatokat alakító közbeszédből és/vagy a szakpolitikai berkekben zajló vitákból egyszerre eredményezheti a javakhoz való hozzáférés (további) korlátozását, illetve egyes társadalmi csoportokhoz kötődő gyakorlatok marginalizációját (Ward 2004). Ez megnyilvánulhat abban, hogy egyes gyakorlatokat az „informális” szféra részeként jelenítenek meg - sok esetben stigmatizálva az érintett társadalmi csoportokat -, vagy oly módon, 
hogy figyelmen kívül - tehát szabályozás, támogatás nélkül - hagyják azokat (Gibson-Graham 2008; Sharp 2011). Az így érvelők az egyenlőtlenségeket újratermelő struktúrák működését és azok diskurzív hátterét a napi társadalmi gyakorlatokon keresztül tartják megragadhatónak, figyelembe véve azok nézőpontját is, akik marginális helyzetűnek tekintik magukat. Ezzel ráadásul elkerülhető a leegyszerüsítő, bináris logikára épülő (fejlett/fejletlen; vesztes/nyertes; formális/informális stb.) tudományos érvelés is (Massey 2008; Sharp 2011). Ez a társadalmigyakorlat-központú vizsgálódás lehetővé tette a kutatók számára a marginalizálódás különböző dimenzióinak (osztály, kultúra, etnikum, életkor, társadalmi nemek stb.) és történeti beágyazottságának - így a posztszocialista átmenet mindennapi életet átformáló következményeinek és a kelet-közép-európai kapitalizmusok sokszínűségének - megértését is (Stenning, Smith, Rochovská, Światek 2011; Williams 2005).

A marginalizálódás térbeli folyamatként történő értelmezését ösztönözte a társadalmi problémák, konfliktusok térbeli koncentrálódása és újratermelődése, e folyamatok lokális terekhez kötődő, eltérő sajátosságainak, illetve a politikai diskurzusok helyeket/tereket marginalizáló szerepének felismerése és vizsgálata (Hörschelmann 2001; Kuus 2013). A kutatók egy csoportja a marginális helyzet összetevőit és mértékét (alacsony jövedelmek, kulturális elszigetelődés, rossz minőségű infrastruktúra, közszolgáltatási deficitek stb.) igyekezett megragadni, hangsúlyozva a már fennáló térbeli különbségeket (pl. Leimgruber 2007).

Az utóbbi évek társadalmi viszonyokra - a marginalizációt mozgató, irányító mechanizmusokra - fókuszáló kutatásainak eredményeként azonban a nemzetközi tudományos vitákban egyszerre több, egymást részben átfedő koncepció is megjelent, amelyek szerint a térbeli marginalizáció értelmezhető úgy, mint:

- leszakadás a „magterületektől”; a folyamat jellemzői az alacsony szintű szükségletkielégítés (foglalkoztatás, fogyasztás, társadalmi részvétel), a társadalmi egyenlőtlenségek és az informális függőségek;

- elégtelen integráció, amely megragadható - a (térbeli) gazdasági-társadalmi kirekesztődésben/elszigetelődésben, a lokális szereplők különböző térbeli léptékekhez kötődő gazdasági és politikai függőségében, az egyenlőtlen csereviszonyokban, a gyenge térségi innovációs potenciálokban;

- gazdasági (tőkevonzás, foglalkoztatás, piaci kapcsolatok stb.), társadalmi (demográfiai folyamatok, tudástőke, közszolgáltatások stb.), politikai (jogérvényesség, érdekartikuláció stb.), kulturális (identitás, közösségi kapcsolatok stb.) hátrányok térbeli halmozódásában, egymást erősítő hatásában (Schmidt 2007).

A fenti vitákból, (távolról sem letisztult) koncepciókból kiindulva a marginalizációt mi is összetett, a mindennapi élet valamennyi területét érintő társadalmi-térbeli folyamatként - a változó társadalmi viszonyok „termékeként” értelmezzük. Ez utóbbiak mechanizmusai a marginalizálódó térségekben élők napi gyakorlatain keresztül ragadhatók meg, következményei pedig az egyének, csoportok és terek egymást erősítő leszakadásában, a társadalom egyes tagjai és 
csoportjai közötti gazdasági, kulturális és politikai távolság növekedésében - az integráció hiányában. Az általunk választott társadalmigyakorlat-központú megközelités lehetővé teszi, hogy a marginalizáció folyamatait, bonyolult lokális és lokalitáson túlnyúló, összetett viszonyrendszereit megértsük, és megjelenítsük a társadalom peremén élők nézőpontjait, „megélt” marginalizáltságát. Ezzel azokhoz a kutatásokhoz is kapcsolódunk, amelyek árnyalt képet igyekeznek adni a vidéki terek átalakulásáról a folyamatot alakító intézményi müködési logikák, diskurzusok és a lokális terekhez kötődő társadalmi gyakorlatok kölcsönhatásainak feltárásával (pl. Cloke 2006; Kovács 2010; Váradi 2005; Virág 2010).

Hogy megérthessük, milyen módon kapcsolódnak össze a társadalmi és a térbeli marginalizáció gyakran elkülönülten vizsgált folyamatai, s feltárjuk a „peremhelyzeteket” újratermelő társadalmi viszonyokat, a kérdéskörhöz kapcsolódó elméleti viták áttekintése mellett empirikus kutatásokat végeztünk négy magyarországi terepen. Ezek kiválasztásához előzetes - kistérségi/járási szinten - statisztikai elemzést végeztünk, hogy áttekintsük a társadalmi-térbeli egyenlőtlenségek demográfiai, foglalkoztatási, jövedelmi-vagyoni, gazdasági, közlekedés-földrajzi és közszolgáltatási-ellátottsági dimenzióit. A kiválasztott sarkadi, mezőkovácsházai, lengyeltóti és sárospataki térségek az általunk vizsgált mutatók szerint a „leszakadók” közé sorolhatók. A korábbi kutatások a rurális, illetve erősen rurális területként definiálták e térségeket (pl. Csatári 2005), és a szakpolitikai vitákban (a fejlesztési dokumentumokban) is hátrányos helyzetű terekként számolnak velük. A különböző földrajzi (természeti adottságok, közlekedési helyzet) és helyi társadalmi-gazdasági kontextusokban történő vizsgálódással az volt a célunk, hogy feltárjuk a vidéki terekben a marginalizációt újratermelő mechanizmusokat, az azokra adott helyi válaszokat.

A terepmunka során kvalitatív módszereket alkalmaztunk. Életútinterjúkat készítettünk helyi lakosokkal, illetve félig strukturált interjúkat gazdasági szereplőkkel, a térségekben működő intézmények tisztviselőivel és civil szervezetek képviselőivel (a négy térségben összesen 78 interjút, 2013 nyarán). Jelen tanulmányban a társadalmi-térbeli marginalizáció folyamatait egyrészt a lakosság három - marginalizált helyzetü - csoportjára (romák, fogyatékkal élők s a nők egyes csoportjai), másrészt a helyi gazdasági szereplőkre fókuszált empirikus kutatásokból kiindulva próbáljuk megragadni.

\section{A marginalizálódás „megélt” tapasztalatai a leszakadó vidéki térségekben}

A vizsgált négy kistérség lakóinak a marginalitásról, a marginalizáció folyamatáról (különösen az integráció hiányáról) szerzett tapasztalatainak, az azokkal összefüggő napi gyakorlatainak számbavételéhez hasznos elemző keretet kínál Castel (1993) koncepciója a „szociális kohézió zónáiról”. E szerint az egyes sze- 
mélyek, társadalmi csoportok a betagolódás - legerősebb társadalmi kohéziót biztosító - társadalmi terétől („zónájától”) a sebezhetőség zónáján át a kiilleszkedési zónáig, azaz a munka nélkül lét és szociális elszigetelődés összekapcsolódásának övezetéig helyezkedhetnek el. ${ }^{1}$ Pozíciójukat két komponens, mint egy „koordinátarendszer” két tengelye jelöli ki. Az egyik a munkához való viszony tengelye (a becsatlakozástól a kizártságig terjedő skálával), a másik a társadalmicsaládi társas kötelékek tengelye (a beilleszkedéstől az elszigetelődésig). Az általunk megkérdezetteket ezért nemcsak a munkalehetőségek hiányával jellemezhető csoportokból választottuk, hanem bizonyos társadalmi kapcsolatokban a diszkriminációt, elutasítást, azaz a marginalizáltság (Barz 2007) veszélyét valószínűsítő csoportokból is (romák, fogyatékkal élők, hátrányos helyzetű, pl. egyedülálló nők). Mivel pedig az etnikai, nemi, testi „másságon” alapuló jelenlegi magyarországi társadalmi kapcsolatrendszerek egyenlőtlenségekkel terheltek, ezek a leszakadó vidéki terekben szinte kivétel nélkül minden interjúpartnerünk munkaerő-piaci esélyeit is rontják. A hatalomban, megbecsültségben, müvelődési lehetőségekben stb. megtapasztalt nélkülözésük mellett általában a fizetett munkához is nehezebben férnek hozzá, így a sebezhetőség zónájából könnyen átkerülhetnek a kiilleszkedés zónájába.

Az egymást erősítő marginalizálódási folyamatok eredőjeként legtöbb interjúpartnerünk anyagi nélkülözést is megél. Helyi társadalmon belüli pozíciójuk meghatározásakor általában a társadalmi polarizáció elmélyüléséről számolnak be, és relativizálják a szegénység fogalmát. Az „elithez” többnyire csak a rendszerváltás utáni mezőgazdasági privatizáció (esetleg örökség) révén meggazdagodott, leginkább az egykori agrárértelmiséghez tartozó mai néhány vállalkozót sorolják (legkevesebb 1-2, legtöbb 10-15). Jellemzően kettéosztják saját településük társadalmát: a minimális számú elitre/gazdagra és a „többiekre”, ahová szerintük maguk is tartoznak. Nem számít azonban kivételnek az a szemlélet sem, melyben a "falu szegénységét” viszonyítási alapnak tekintve relatíve javul a személyes pozíció megítélése. Mint egyik interjúalanyunk fogalmaz: „A mi családunk [országosan] nagyon alsó osztályba [tartozik]. Épp csak, hogy megélünk. (...) Itt [a faluban] gyenge közép.” Az ilyen „középre” sorolásokban az is kifejeződhet, hogy az „abszolút szegénység” mércéjét napjainkra egyértelműen az ételhez jutás szintjére szállították le a megkérdezettek. Egy roma interjúpartnerünk például az „erős középhez” tartozókat is úgy definiálja, hogy ők olyanok, akik „mindent meg tudnak fözni, és minden nap, rendesen". Ezért, bár meglehetősen súlyos anyagi gondokkal küzd a családja, viszont nem éheznek, nem is definiálja magát szegénynek.

A kapitalizmus lényegét adó munka-tóke viszonyon „kívülre” szorulásukról számos tapasztalatot osztottak meg velünk interjúpartnereink. A nők úgy vélik, számukra eleve rosszabb a helyi munkahelykínálat. A megszigorított közmunkák szervezésében pedig csak a polgármester jóindulatától függ, hogy mennyire vannak tekintettel a munkaidő beosztásánál a gyereknevelésből adódó sajátos igényekre. Ugyanezen igények miatt sokkal nehezebb a nőknek falujukon kívül is munkát találni. Nem egyedi eset, hogy elutasítóvá válik a munkáltató, amint 
tudomást szerez a jelentkező nő kicsi és/vagy több gyermekéről. A fogyatékkal élók, még ha volna is számukra elvégezhető munka valamely közelebbi-távolabbi városban, a tömegközlekedés akadálymentesítése és a megfelelő saját anyagi források híján nem tudják megoldani az ingázást. Korábbi Békés megyei kutatásaink tapasztalataival (Timár, Fabula 2013) való egyetértését fejezte ki az az interjúpartnerünk, aki aláhúzta: a fogyatékosságnak „teljes mértékben vonzata a szegénység". Szalai Júlia (2002) az ezredforduló idején a magyarországi kirekesztésnek két kollektív formáját írta le: az egyik a területi egyenlőtlenségekhez kötődik s az aprófalvas települési zárványokban, depressziós térségekben élőket érinti, míg a másik etnikai eredetü, s a cigány lakosság többségét kitevő szegényeket sújtja. Roma interjúpartnereink egyszerre élik meg e kétfajta szorítást. Az ,itt nincs semmilyen munka” panasza egyértelmüen kiegészül a „mi nem kapunk munkát” saját, esetleg családtagtól, baráttól hallott történeteivel. Egy rövid projekt keretében romafoglalkoztatás-szervezőként dolgozó, felsőfokú végzettségű cigány interjúpartnerünk átfogóbb tapasztalatokat fogalmaz meg:

„Én azt tapasztaltam, sajnos, hogy hiába tanul az, aki echte cigánynak néz ki, fekete a böre vagy sötétbarna a böre, sajnos tényleg hátrányokat szenved, és nem adnak neki még csak lehetöséget sem, hogy gyakorolja a szakmáját, ha egyáltalán van. Ha meg nincs, még egy kubikmunkára sem alkalmazzák, maximum az önkormányzat egy közmunkaprogramon belül. Tényleg nincs kilátása a cigányságnak. Mindig azt mondják, hogy illeszkedjenek be. Nincs hova."

A megkérdezettek családi-társadalmi kapcsolatok tengelyén elfoglalt helye személy-, csoport- és településfüggő tulajdonságokat is mutat. A marginalitás egyedi példáinak látszanak az olyan élettapasztalatok, mint azé az interjúalanyé, aki férje erőszakossága miatt szétzilált családi kapcsolatait ecsetelte, vagy azé az elszegényedése miatt fizikai elzártságba kényszerült mozgáskorlátozott asszonyé, aki azt fájlalja legjobban, hogy már az unokáját sem képes meglátogatni. Mégis, egyértelműen kirajzolódnak mögöttük a patriarchális és az „épségnormatív" társadalmi viszonyok. Ami a települési léptéket illeti: vannak a vizsgáltak között például konfliktusmentes roma-magyar együttéléssel jellemzett falvak, de olyanok is, ahová interjúpartnereink szerint „már roma nemzetiségü nem költözhet be". Amiben viszont közösek a lakóhelyek értékelései: a falusiak egyöntetűen hátrányos helyzetűnek, leszakadónak, elmaradottnak, perifériának találják településüket, térségüket. Olyan helynek, ami - bár legtöbben kötődnek hozzá - nem képes munkát, perspektívát nyújtani gyermekeiknek sem.

A vizsgált falvak, térségek sem integrálódnak tehát megfelelően az elsődleges munkaerő-piaci folyamatokba: távol maradnak a befektetők, nem állnak rendelkezésre újabb munkahelyek. Ráadásul a marginalizáció térbeli és társadalmi dimenziójának itt leírt egybefonódása miatt - akárcsak a nyugati országok polarizálódó nagyvárosaiban (Wacquant 2011) - már nincs meg az a közösségi háló, az a segíteni képes „hátország” sem, amelyre a munkaerőpiacról 
időlegesen kiszorultak támaszkodhatnának. Sokuk számára ezért az a tipikus válasz, hogy beépítik a stratégiáikba a segélyen élést. Jó példa erre a fogyatékossági státusz „védelme” akkor is, ha azt stigmatizálásként éli meg az érintett. A munkanélküliséggel sújtott családtagok érdeke is ahhoz füződik, hogy a „nehezen megszerzett", kis összegü, de egy minimálbéres, szerződés nélküli álláshoz képest biztos jövedelemnek számító ápolási díjat, illetve az ehhez való jogosultságukat megőrizzék. Így bizonyos értelemben a családra is kiterjed a fogyatékkal élők marginalizáltsága, ami tovább gyengíti falujuk integráltságát, újratermeli az épségnormatív társadalmi viszonyokat, növeli az államtól való függőséget. Hasonló módon termeli újra a marginalizáltságot és erősíti a függőséget a polgármesterektől a közmunkaprogramok rendszere, továbbá az idény-, illetve feketemunkát biztosítani képes egy-két vállalkozótól a kizsákmányoló, „törvényen kívüli” munkák kényszerű elvállalása.

A társadalmi marginalitásból való kiszabadulás, a marginalizált térségből menekülés egyetlen, még realitásnak vélt lehetőségének a fizetett munkához juttató migrációt látják interjúpartnereink. Az állami lakáspolitika, a szociális lakások hiánya azonban alapvetően gátolja az elköltözést. Ugyanakkor az ingatlanpiaci viszonyok eladhatatlanná teszik a szocialista időszakban az egyetlen befektetésként felépített nagy falusi házakat, illetve a családosok nem merik kockáztatni mindannyiuk otthonát a hosszú távon teljesen bizonytalan fővárosi, külföldi stb. munkalehetőségért. A migráció ezért (is) szelektív folyamat. A hátramaradottakkal pedig tovább nő a falun élő, marginalizálódó, függőségi rendszerekbe szorított társadalmi csoportokhoz tartozók aránya, mindinkább csökkentve ezzel az egész település integráltságát, azaz fokozva marginalizálódását.

Néhány magyarországi statisztikai elemzés azt mutatja, hogy már jelenleg is regisztrálható bizonyos marginalizálódó társadalmi csoportok koncentrálódása a hátrányos helyzetű, leszakadó térségekben, településekben (lásd a fogyatékkal élők falvakban, gazdaságilag fejletlenebb térségekben kimutatható relatíve nagyobb arányát (Fabula 2010); a jellemzően romák lakta települések növekvő népességkoncentrációját a gazdaságilag elmaradott régiókon belül (Pásztor, Pénzes 2012). Az 1990-es évektől szegregálódó/gettósodó aprófalvak, sőt falusi térségek jelenlétét mutatják ki a kutatások (pl. Bihari, Kovács 2005; G. Fekete 2005; Ladányi, Szelényi 2004; Virág 2010). Interjúalanyaink tapasztalatai azt támasztják alá, hogy lakóhelyeik marginalizációja, a makrotársadalmi, gazdasági-hatalmi viszonyok és folyamatok (pl. egyenlőtlen térbeli fejlődés, kormányzati politikák, munkapiaci, patriarchális, épségnormatív viszonyok) erősen leszükítik a marginalizálódó társadalmi csoportok cselekvési terét. Ezért a strukturális tényezőkkel együtt az ő legkézenfekvőbb válaszaik is gyakran csak a „napi túlélésre” nyújtanak megoldást. Hosszabb távon a saját és/vagy a falujuk, „vidékük” függőségi viszonyainak és a társadalmi-térbeli marginalizációnak újratermeléséhez és kölcsönös erősítéséhez járulnak hozzá. 


\section{A gazdasági szereplők stratégiái és változó függőségi viszonyai a vidéki terekben}

A rendszerváltozáshoz kapcsolódó neoliberális (a piaci nyitást és a magántulajdon kiterjesztését elősegítő) intézményi reformok versenycentrikus megközelítésükkel „piacositották” a rurális térségek erőforrásait - a szabad munkaerőt, a földvagyont, az ingatlanokat, az itt élők által felhalmozott tudáskészletet és társadalmi kapcsolatrendszereket. A piaci mechanizmusok - $\mathrm{s}$ az azok differenciáló hatását inkább erősítő, mint enyhítő állami intézményi gyakorlatok - jelentős részben leértékelték ezeket az erőforrásokat, ezzel társadalmi csoportokat és tereket marginalizálva (Bihari, Kovács 2005; Csurgó, Kovách, Megyesi 2009; Nagy 2005). Az alábbiakban azt mutatjuk be, hogy a vizsgált térségek gazdasági szereplői gyenge piaci beágyazottságuk, erős függőségre épülő kapcsolatrendszereik és társadalmi környezetük kedvezőtlen folyamatai eredőjeként milyen stratégiákat alakítanak ki, és napi gyakorlataikkal hogyan erősítik tovább a helyi, térségi marginalizációs folyamatokat.

A négy kutatási terepen felkeresett 38 vállalkozó döntő többsége saját térségét „leszakadónak”, ,perifériának” vagy „marginális helyzetűnek” tekinti a dinamikus gazdasági központoktól való fizikai távolságuk, a helyi munkaerő leértékelődése, a térség információáramlásban elfoglalt helyzete, a köz- és üzleti szolgáltatások hozzáférhetősége és az itt élők érdekérvényesítő képességének hiánya miatt. Saját vállalkozásuk helyzetét jóval kedvezőbben ítélik meg, az egyedi értelmezések azonban jelentős eltérést mutattak ágazatonként, a tulajdonosi szerkezet, a méret, a piaci kapcsolatrendszerek (lokális/belföldi/globális) és a tevékenység lokális környezete (falu/város; a helyi kormányzás minősége) szerint. Négy terepünkön szerzett tapasztalatainkat összegezve három karakteres csoportot sikerült elkülöníteni a helyi vállalkozók körében: a globális termelési láncokba beágyazódókat, a függö helyzetü mezögazdasági termelóket, illetve a helyi szolgáltatókat. Az utóbbi csoportból itt csak a helyi kiskereskedőkkel foglalkozunk.

A beágyazódók csoportját viszonylag kisszámú vállalkozás alkotja, mégis fontos a szerepük a térségi folyamatokban. ők kapcsolják be közvetlenül a helyi szereplőket a globális termelési hálózatokba, jelentős a szerepük a térségi foglalkoztatásban (az alkalmazottak létszáma és ennek viszonylagos stabilitása, a folyamatos képzés és az általuk biztosított, kiszámítható munkaerő-piaci feltételek miatt), továbbá a szakmai, illetve piaci információk és tudás - szervezetiirányítási modellek, üzleti stratégiák stb. - közvetítésében. Gyakorlataikban tetten érhetők a globális gazdasági folyamatok, a különböző (európai, nemzeti, helyi/térségi) intézményi kontextusok és a lokális társadalmi folyamatok kölcsönhatásai, konfliktusai (Coe, Dicken, Hess 2008).

A csoportba sorolt vállalkozások üzleti stratégiájának egyik fontos eleme $a$ helyi, nehezen mobilizálható erőforrások (termőföld; olcsó, hasznosítatlan telephelyek, ingatlanok) hasznositása. Ezek térbeli rögzítettsége azonban kiaknázható előnyöket is jelentett. ${ }^{3}$ Egyrészt a rendszerváltozást követő strukturális válság- 
hoz kötődő leértékelődésük, majd a vizsgált térségeket hosszú távon marginalizáló globális és hazai ingatlanpiaci folyamatok olcsó álló tőkét biztosítottak az induláshoz, majd a terjeszkedéshez. Másrészt a rurális térségeket megcélzó regionális (LHH) és vidékfejlesztési programok keretében megvalósított beruházásokkal ezek a cégek voltak képesek technológiai modernizációra, a telephelyek korszerüsítésére, amivel növelték ezek értékét, s csökkentették működési költségeiket - ami biztosította helyüket (versenyképességüket) a globális piaci kapcsolatrendszerekben. Mivel a fejlesztési források megszerzése (tudás-, kapcsolati és pénz-) tőkeigényes folyamat, a terepeinken felkeresett összes vállalkozás közül lényegében csak a „beágyazódók” egy része húzhatott hasznot a vizsgált térségek marginalizált ingatlanpiaci helyzetéből és fejlesztéspolitikai célterületként történő kijelölésükből.

A beágyazódók stratégiáinak másik fontos pillére a térségben elérhető szabad munkaerő, amelynek kiaknázása - pl. a bérek alacsony szinten tartásával - a tőkefelhalmozás forrása (Harvey 2003; Welch, Dear 2005). Terepeinken a bérszínvonal országos összehasonlításban kifejezetten alacsony, csekély mértékben vagy egyáltalán nem haladja meg a minimálbér (szakmunkások esetében a szakmai minimálbér) összegét. Ezt a gyakorlatot a felkeresett vállalkozók tisztességesnek tartják a helyi/térségi viszonyok között. Ugyanakkor a helyi munkaerő-kínálatot szakmai tudás és készségek, illetve munkakultúra szempontjából is kifejezetten problematikusnak („,szegényesnek”) tartják. Munkaerő-toborzási gyakorlataikban ezért a személyes ismertség felértékelődött, sőt, a vállalkozások többsége számára fontosabbá vált az intézményi (szakképzőkkel, munkaügyi hivatalokkal kialakított) kapcsolatoknál. A lokális (térségi) kapcsolati hálókra épülő szelekciós mechanizmusok érintik a közmunka szféráját is: akik az utóbbiban „jól teljesítenek”, alkalmi munkát kaphatnak a helyi vállalkozóknál is. Ezt jól illusztrálja egy nemzetközi piaci kapcsolatokkal rendelkező észak-békési agrárvállalkozó foglalkoztatási stratégiája:

„Amikor elindult a vállalkozás a tsz felbomlása után, kiválogattuk a jó szakembereket, ők jórészt máig itt dolgoznak. Szerencsések voltunk. Utánpótlást persze keresünk, szükség van a fiatalításra... Őket személyesen keressük meg, tudjuk, melyik családhoz kell menni. De azért igyekszünk kiváltani a munkaerőt gépesitéssel, mert [az élőmunka] drága és nem is megbízható... Inkább csak idénymunkára kellenek többen, havi 5-7 napra. A kapások nagy része közmunkás is volt, ismerjük óket. A többieket kiközvetítik a helyi cigány vezetök, ők céget is alapitottak erre..."

A feltárt, formális és informális kapcsolatokra épülő foglalkoztatási gyakorlatok egyrészt hozzájárulnak a térségben élő munkavállalók marginalizációjához az alacsony bérszínvonal fenntartásával, másrészt egyes csoportokat $a$ térségen belül is marginalizálnak. Az interjúpartnereink a roma családok többségét, a könnyüipari üzemek bezárása után nehéz helyzetbe került nőket sorolták az utóbbi körbe. Hangsúlyozták ugyanakkor, hogy a munkaerő-piaci marginalizálódás egyre kevésbé kötődik etnikumhoz, sokkal inkább a fennálló piaci-in- 
tézményi struktúrák keretei között újratermelődő, térségükben egyre gyakoribb élethelyzetek „terméke”.

A beágyazódók stratégiáinak harmadik pillérét olyan tudás- és kapcsolatitőke-elemek jelentik, amelyeket hosszabb távon halmoztak fel. E vállalkozások többségének kapcsolatrendszereire a kisszámú szereplővel szembeni erős függőség és éles versenyhelyzet jellemző. Ezért különösen fontos számukra az innovációkhoz szükséges nem materiális tőkék felhalmozása, ${ }^{5}$ hogy fenntarthassák vagy megváltoztathassák a globális termelési hálózatokban betöltött szerepüket. Ezek a tőkék csak részben állnak rendelkezésre a felkeresett - többnyire kis-, ritkábban közepes méretü - vállalkozások keretein belül, ezért a térségen kívüli szolgáltatókkal fenntartott formalizált kapcsolatokra kell támaszkodniuk. Részben ezzel, részben a mind bonyolultabbá váló intézményi gyakorlatokkal (pályázati rendszer; napi működést meghatározó szabályozók) magyarázzák saját marginalizálódásukat az információáramlásban. Nem meglepő tehát, hogy kevés esetben (leginkább a gépiparban és néhány, nagyobb méretű agrárvállalkozásnál) találkoztunk olyan „hibrid” stratégiákkal, ${ }^{6}$ amelyek erős specializációra, szervezeten belüli tanulási folyamatokra, technológiai innovációkra épültek, és alapjául szolgáltak a termelési hálózatokon belüli függőség mérséklődésének.

A második vállalkozói csoport, a függő helyzetü mezőgazdasági termelók csoportjának kiemelését az indokolja, hogy terepeinken az összes regisztrált vállalkozás 58-67\%-a közülük kerül ki. A csoport döntően tőkeszegény, viszonylag kis területen gazdálkodó egyéni vállalkozásokat foglal magában. Ez a csoport a térségi piacokat ellenőrző (oligopol státuszú), ma már zömmel a térségen kívülről érkező közvetítőkön - nagy- és kiskereskedőkön, ritkábban ágazati integrátorokon - keresztül kapcsolódik a globális termelési hálózatokhoz, és túlélésük erősen függ a piaci mozgásoktól és a környezeti tényezőktől is. Ugyanakkor mind a kockázatokat kezelő piaci intézményi gyakorlatokban (biztosítások), mind a tőkeáramlásban - a bankok hitelezési gyakorlataiban - marginális a helyzetük. Interjúink szerint ez utóbbit erősítette a sajátos, személyes kapcsolati hálókhoz kötődő hitelezési gyakorlatot folytató takarékszövetkezeti hálózat átalakítása (,,bankosítása”) is.

Mivel e csoport vállalkozásai nem rendelkeznek elegendő (pénz-, tudás- és kapcsolati) tőkével, amire szükségük lenne a globalizált piaci versenyben, így az utóbbi évtizedben stratégiáikat növekvő mértékben határozza meg a hazai és uniós agrárpolitika szabályozási-támogatási rendszere. Mindez egyszerre a stabilitás és a marginalizálódás forrása számukra: a támogatási rendszeren keresztül jutnak hitelekhez és biztos jövedelemhez, ugyanakkor a mind bonyolultabb intézményi gyakorlatok többségük számára átláthatatlanok, ${ }^{7}$ ezért rendszeresen rászorulnak a térségi központok hivatalaiban elérhető segítségre. ${ }^{8}$ Az agrárkamara egyik helyi munkatársa szerint „a jelenlegi szabályozás teljesen átláthatatlan a gazdálkodók kb. 95\%-a számára (...) a kamara nélkül esélyük sem lenne kitölteni a megfelelö ürlapokat, pedig a támogatási rendszer nélkül a kisgazdaságok életképtelenek, a sikeres gazdálkodáshoz szükséges tudás a tsz-ben maradt, nekik csak a föld van, semmi más." 
E csoport marginális helyzetének oka a helyben elérhető tudás és információk hiánya, illetve gyenge minősége - amiben fontos szerepe van a szakértelmiség elvándorlásának és a helyi-térségi kapcsolati hálók ezzel összefüggő meggyengülésének. Másrészt azzal is magyarázható, hogy a függő helyzetű mezőgazdasági termelők csoportja nem rendelkezik politikai befolyással - a meglevő szakmai hálózatokon keresztül sem - az őket marginalizáló intézményi gyakorlatok megváltoztatásához. ${ }^{9}$

Nem meglepő tehát, hogy interjúink szerint e vállalkozói csoport ${ }^{10}$ üzleti stratégiái ritkán mutatnak túl az önfoglalkoztatáson és a túlélésen. Legtöbbször azonban ehhez is új függőségeken át vezet az út - függnek a szakpolitika intézményeinek tisztviselőitől (azok kompetenciájától), a globális piaci folyamatokat közvetítő felvásárlóktól és az ágazat helyi meghatározó szereplőjétől/szereplöitől, akik szolgáltatóként és tudásközpontként is müköd(het)nek. Ezeket a viszonyokat újratermelik a szakpolitikák hosszabb távú strukturális hatásai: elsősorban a termelési struktúra leegyszerüsödése és a helyi/térségi specializáció gyengülése. A fenti folyamatok végső soron - a politikai törekvések ellenére - a birtokkoncentrációt erősítik, és gyengítik a helyi közösségek lokális erőforrások (tőkék) fölötti ellenőrzését.

A vizsgált térségekben élők fogyasztóként is „megélték” a marginalizációt. Ennek hátterében alapvetően a kereskedelem szerkezeti átalakulása áll. A folyamat meghatározó szereplőinek - a kereskedelmi befektetőknek - stratégiái a térbeli koncentrációt erősítették, hozzájárulva a rurális térségek marginalizációjához. Az ágazat helyi szereplőinek (vállalkozóinak) egyszerre kellett számolniuk a városokban megjelenő új kereskedelmi terek szívóhatásával és a csökkenő helyi kereslettel, továbbá az élesedő piaci versennyel, amit - a kereskedelemben gyorsan terjedő technikai és szervezeti innovációk mellett - a tőkeerős szereplők körének bővülése is ösztönzött.

A marginalizációs folyamatokat erősítették a helyi szolgáltatók válaszai is. Mivel fogyasztóik növekvő számban a nem mobil, alacsony jövedelmű csoportokból kerültek ki, szükítették a kínált áruk körét, és csak az elengedhetetlennek ítélt technikai újításokat vezették be. Emellett változtattak térbeli stratégiáikon is: ha tehették, csak a központi fekvésű vagy magasabb jövedelműek lakta településrészeken tartották meg boltjaikat, illetve korlátozták a fogyasztók mozgásszabadságát térfigyelo kamerákkal és/vagy a hagyományos „pult mögüli" árusítás visszaállításával. Az utóbbit a romló közbiztonsággal magyarázták, amit az interjúpartnerek egyértelműen a helyi roma közösséggel hoztak kapcsolatba, kimondatlanul is „alacsonyabb rendü" vásárlóknak tartva őket. Ezek a folyamatok több, általunk vizsgált településen (és nem csak az aprófalvakban) az alapvető napi cikkekhez való hozzájutást is megnehezítették. A helyzetet súlyosbítja, hogy a marginalizáció mérséklésének hagyományos útjai - saját „háztáji” termelés, szomszédi, rokoni segítségnyújtás - eltűnőben vannak a mélyülő szegénység és a nyomott élelmiszerárak miatt. A napi problémák mellett a fogyasztás társadalmistátusz-képző szerepén keresztül is marginali- 
zálja a vizsgált térségek lakóit, ${ }^{11}$ aminek a materiális javak mellett számos - szabadidős, egészségügyi, kulturális - dimenzióját említették még a térségekben élők. Az egyik közepes méretü falu polgármestere szerint „a helyi lakosság ellátásának alapvető feltételei sincsenek meg; a többség baráti, rokoni szívességektól függ, egy mozi vagy egy koncert pedig végképp elérhetetlen. Ugyan ki tudná megfizetni a belépők mellett a buszjegyek árát is?"

Habár a rendszerváltás időszakától a gazdasági liberalizáció folyamatai és az állam szerepének változása hanyatló-leszakadó pályára állította a vizsgált térségek gazdaságát, a helyi vállalkozók igyekeztek „piackonform” válaszokat találni mind a makrokörnyezet változásaira, mind azok lokális következményeire. Mindezt nagymértékben befolyásolták a rendszerváltozás időszakában, illetve még korábban felhalmozott erőforrások; hasznosításuk módját azonban a vállalkozók által kialakított stratégiák és napi gyakorlatok határozták meg, amelyek a formalizált piaci és a helyi beágyazottságú (részben informális) társadalmi kapcsolatrendszerek kombinációjára épültek. E stratégiák egyrészt új, különböző földrajzi léptékekhez, terekhez kötődő függőségeket is teremtettek, másrészt hozzájárultak a helyi társadalom különböző csoportjainak további marginalizálódásához is.

\section{Marginalizálódás a vidéki terekben - a vidéki terek marginalizációja}

Kutatásaink szerint a marginális helyzetek újratermelődésében összekapcsolódnak - sok esetben egymást erősítik - a piachoz, az állam intézményeihez és a helyi „civil” társadalomhoz kötődo" gyakorlatok. A vizsgált térségekben élők tehát munkavállalóként, a piaci és a közjavak fogyasztójaként, politikai cselekvőként, valamely kulturális vagy etnikai csoport tagjaiként, mint nők/férfiak, esetleg fogyatékkal élők is megtapasztalják a kiszorítottságot, a társadalmi marginalitást. Peremhelyzetüket, kiszorítottságukat ugyanakkor településük, térségük lakosaiként is naponta átélik. A tereket marginalizáló intézményi gyakorlatok megragadhatók többek között a munkahelyek elérésének - különösen a romákat, fogyatékkal élőket és a nőket sújtó - problémáiban, a bérek egyenlőtlenségeiben, a közszolgáltatások minőségi különbségeiben és hozzáférhetőségében, és a fogyasztás tereinek koncentrációjában épp úgy, mint a civil aktivitás hiányában a lakóhelyi szegregációban, és általában az életfeltételek újratermelődő különbségeiben a települések között és azokon belül is.

Az állami intézmények, amelyek a társadalmi-térbeli különbségek mérséklését, az integrációs folyamatokat hivatottak segíteni, nem töltötték be ezt a szerepüket az elmúlt két és fél évtizedben. A közszolgáltatások fedezetét biztosító források folyamatos szűkítése, a reintegrációs kezdeményezések gyengesége, esetlegessége/hiánya, és - e feltételek mellett - az állami alapszolgáltatások 
helyi önkormányzatokon keresztül történő szervezése is a vidéki térségek marginalizációs folyamatait erősítették. A szolgáltatások minőségi különbségei (például az oktatásban) egyértelműen a térbeli egyenlőtlenségek újratermelődését, sok esetben a szegregációt erősítették a vidéki terekben is (Kertesi, Kézdi 2004). Mindez gyorsította a helyi közösségek szétesését, és erősen korlátozta, korlátozza a marginális helyzetekre adható válaszokat. Ugyanakkor a források elosztásának versenyalapú megközelítése - a fejlesztéspolitikában, és az utóbbi években a szociális problémákat kezelni hivatott közmunkaprogramokban - ugyancsak a leszakadó településeket érintette hátrányosan (Koós 2013; Kovách 2012). Az elmúlt évek széles körü recentralizációs (,államosítási”) folyamatai - miközben nem orvosolták a fentebb említett problémákat - a lokális intézmények (elsősorban az önkormányzatok) központi államhatalomtól való függőségét erősitették. Az alávetettség új intézményi és személyes formáit hozták létre a marginalizálódó térségekben, például a közmunkaprogramokon keresztül.

A helyi társadalom csoportjai, tagjai marginális helyzetüket eltérő módon élik meg, értelmezik, és „fordítják le” napi gyakorlatokra, amelyek minden esetben saját lokális tereik (településrészük, településük, térségük) marginalizációs folyamataihoz ${ }^{12}$ kötődnek. Az itt élők többsége nem rendelkezik olyan (tudás-, pénz-, kapcsolati-) tőkével, ami lehetővé tenné a kitörést a marginális helyzetből, akár migrációval - ami tovább erősíti a térség demográfiai, társadalmi, gazdasági erózióját -, akár vállalkozóvá válással, akár helyi összefogással. E lehetőségeket az értelmiségiek elvándorlása, az őket foglalkoztató, közösségi térként is működő intézmények bezárása, a finanszírozási problémák - a helyi források hiánya és a zsugorodó támogatási rendszer - is korlátozzák. A marginalizálódó térségekben élők nagy részének napi gyakorlatait így olyan, erős függőségen alapuló viszonyrendszerek határozzák meg, amelyek ugyan lokális terekhez és szereplókhöz helyi vállalkozókhoz, állami intézményekhez - kötődnek, de a globális piaci folyamatok és a központi kormányzati politikák is alakítják őket. A leszakadó vidéki térségek lakói az egyenlőtlenségeket enyhítő állami beavatkozások és saját tőkék híján újratermelik napi gyakorlataikkal térségük és saját maguk marginalizálódását.

\section{Köszönetnyilvánítás}

A kutatás a Magyar Tudományos Akadémia és a Magyar Nemzeti Vidéki Hálózat közötti együttműködésen alapuló komplex kutatási program keretében zajlott, a Nemzeti Agrár-szaktanácsadási, Képzési és Vidékfejlesztési Intézet megbízásából, A vidékiségból adódó marginalizálódás társadalmi, gazdasági, települési/térségi összetevői, konfliktusai, okai és a feloldás, kezelés lehetőségei c. altémához kapcsolódva. Jelen tanulmány a kutatás empirikus eredményeire épülő, de eltérő fókuszú (kérdésfeltevésü) nemzetközi publikáció hazai közönségnek szánt új változata. 


\section{Jegyzetek}

1 Meg kell jegyezni, hogy Castel (1993) egy negyedik övezetet is megkülönböztetett, amelynek a „segélyezés zónája” nevet adta. Ezt az övezetet a munkaképtelenség okozta munka nélkül lét és a szociális lét erős kötésének együttesével jellemezte.

2 Az „ableist” fogalom magyarra ültetése. Fabula $(2014,34$.) „épségnormativitáson mindazokat a kulturális és materiális tényezőket, és ezek összefüggésrendszereit” érti, „amelyek egy idealizált ép (vagyis bizonyos standardok alapján kinéző és funkcionáló) test-elmét tekintenek univerzálisnak, és ezzel olyan társadalmi tereket hoznak létre, amelyek az idealizálttól eltérő embereket alávetettségben tartják." Ebben a tanulmányban ezt az értelmezést használjuk.

3 A leértékelődő ingatlanok újrahasznosítása a vidéki terekben éppen úgy a tőke térbeli logikájának a megnyilvánulása, mint a városi tereket átformáló befektetői döntések, amelyek célja a tőkehozamok növelése megváltozott térhasználat révén (lásd Smith 1996 járadékkülönbözettel kapcsolatos elméletét). A vizsgált vidéki terek leértékelődése, illetve ennek (erősen szelektív, így nem kifejezetten látványos) kiaknázásában összekapcsolódnak a lokális és globális folyamatok, továbbá a különböző területi szintekhez kötődő intézményi gyakorlatok.

4 A nők munkaerő-piaci marginalizációja más térségekben is a szegénység újratermelődésének kulcsfontosságú mechanizmusává vált (Váradi 2005).

5 A kérdéskörhöz kapcsolódóan lásd pl. Kalantaridis, Vassilev, Fallon (2011); Letenyei (2000).

6 A globális értéktermelési hálózatokban résztvevő vállalkozások stratégiatípusairól posztszocialista kontextusban lásd pl. Pickles, Smith (2011); Pavlínek, Domanski, Guzik (2009).

7 A legtöbbször említett példa az Agrár-környezetgazdálkodási Program végrehajtásával kapcsolatos mulasztások és büntetések nagy száma, ami kétségtelenül a sok adminisztráció következménye; a kisebb gazdálkodók még csak nem is ismerik a belépéssel járó kötelezettségeket, így a dokumentálással kapcsolatos elvárásokat sem.

8 A hazai agrár- és vidékpolitikai intézményrendszer többszöri átszervezése is a kiszolgáltatottságukat erősítette, hiszen a napi működéshez kért/kapott segítség „,bizalmi viszonyra” épül - az $\mathrm{NVH}$, illetve az Agrárkamara szakemberei belelátnak a vállalkozások működésének részleteibe. Ugyanakkor a hivatalok együttműködése - csakúgy, mint a hivatal és a gazdák viszonya - kifejezetten személyes nexusok függvénye, s az átszervezések éppen ezeket szüntetik meg.

9 Ezt kamarai és helyi vállalkozókkal készített interjúink is megerősítették.

10 Interjúink szerint a függő helyzetű mezőgazdasági termelők köre is erősen differenciálódik: a falvakban élő, kevésbé képzett, idősebb gazdálkodókat érintik elsősorban a fent vázolt marginalizációs folyamatok.

11 Terjedelmi okok miatt itt nem tárgyaljuk, de hosszabb elemzésre érdemes a fogyasztáshoz és vidékiséghez kötődő identitások változása, ami fontos szerepet kapott a posztszocialista (Mansvelt 2006; Smith, Jehlicka 2007), s általában, a vidéki társadalmak átalakulásában (Marini, Mooney 2006). Terepeinken a „vidéki fogyasztó” egyértelműen a marginalizáltság szinonimájaként került elő.

12 Ez megragadható a szegénység helyi körülményekhez viszonyított meghatározásában épp úgy, mint a felkeresett vállalkozások intézményi gyakorlatok megváltoztatására tett kísérleteinek kudarcaiban, amit ők összefüggésbe hoztak térségük gyenge politikai érdekképviseletével.

\section{Irodalom}

Barz E. (2007): A marginalizáció szociálantropológiája. Jegyzetek Isabel Martinez Portilla előadásának anyagából. In A. Gergely A., Bali J. (szerk): Városantropológiai vázlatok és változatok. A városmegismerés kérdőjeleiből. MTA PTI Etnoregionális Kutatóközpont, ELTE BTK Néprajzi Intézet, Budapest, 293-308. 
Beluszky P., Sikos T. T. (szerk.) (2007): Változó falvaink. Tizenkét falurajz Kercaszomortól Nyírkarászig. Akadémiai Kiadó, Budapest

Berndt, M., Colini, L. (2013): Exclusion, marginalization and peripheralization. Leibniz Institute for Regional Development and Structural Planning, Berlin (Working Paper; 49.)

Bihari, Zs., Kovács, K. (2005): Slopes and slides: Spatial inequalities in employment opportunities at the turn of the millennium. In: Barta, Gy., G. Fekete, É., Szörényiné Kukorelli, I., Timár, J. (eds.): Hungarian spaces and places: Patterns of transition MTA RKK, Pécs, 360-377.

Castel, R. (1993): A nélkülözéstől a kivetettségig - a „kiilleszkedés” pokoljárása. Esély, 3., 3-23.

Cloke, P. (2006): Conceptualizing rurality. In: Cloke, P., Marsden, T., Mooney P. H. (eds.): Handbook of rural studies. SAGE, London, 18-29. http://doi.org/z7f

Coe, N. M., Dicken, P., Hess, M. (2008): Introduction: global production networks - debates and challenges. Journal of Economic Geography, 3., 267-269. http://doi.org/cwgsq5

Csatári B. (2000): Kísérlet a magyarországi kistérségek komplex fejlődési típusainak meghatározására. In: Dövényi Z. (szerk): Alföld és nagyvilág. MTA FKI, Budapest, 151-167.

Csatári, B. (2005): Criteria of rurality for the Hungarian micro-regions: Major problems facing rural areas in Hungary. In: Barta, Gy., G. Fekete, É., Szörényiné Kukorelli, I., Timár, J. (eds.): Hungarian spaces and places: Patterns of transition. MTA RKK, Pécs, 466-482.

Csurgó B. (2007): Képek és képzetek a mai magyar vidékről. In: Kovách I. (szerk.): Vidékiek és városiak. A tudás-és imázshasználat hatásai a vidéki Magyarországon. L'Harmattan, MTA PTI, Budapest, 45-66.

Csurgó B., Kovách I., Megyesi B. (2009): Helyi hálózatok Európában és Magyarországon. Politikatudományi Szemle, 2., 120-141.

Enyedi Gy. (1996): Regionális folyamatok Magyarországon. Hilscher Rezső Szociálpolitikai Egyesület, Budapest

Fabula Sz. (2010): A magyarországi fogyatékkal élők hátrányos helyzetének néhány területi, települési vonatkozása. In: Csapó T., Kocsis Zs. (szerk.): VI. Településföldrajzi Konferencia (2009. dec. 3-4.): A településföldrajz aktuális kérdései. Savaria University Press, Szombathely, 204-215.

Fabula Sz. (2014): A fogyatékosság mint társadalmi-térbeli viszony földrajzi vizsgálata. Doktori (PhD) értekezés. SZTE Földtudományok Doktori Iskola, Szeged

G. Fekete, É. (2005): Small villages undergoing transformation. In: Barta, Gy., G. Fekete, É., Szörényiné Kukorelli, I., Timár, J. (szerk.): Hungarian spaces and places: Patterns of transition. MTA RKK Pécs, 483-500.

Gibson-Graham, J. K. (2008): Diverse economies: performative practices for 'other worlds'. Progress in Human Geography, 5., 613-632. http://doi.org/cwxkm8

Halfacree, K. (2007): Trial by space for a 'radical rural': Introducing alternative localities, representations and lives. Journal of Rural Studies, 2., 125-141. http://doi.org/fqr53k

Harvey, D. (2003): The new imperialism. Oxford University Press, Oxford

Hörschelmann, K. (2001): Breaking ground - Marginality and resistance in (post) unification Germany. Political Geography, 8., 981-1004. http://doi.org/chwh9c

Kalantaridis, C., Vassilev, I., Fallon, G. (2011): Enterprise strategies, governance structure and performance: Comparative study of global integration. Regional Studies, 2., 153-166. http://doi.org/d4rqdr

Kertesi, G., Kézdi, G. (2004): Primary school segregation. Causes and consequences. Budapesti Corvinus Egyetem, MTA Közgazdaság-tudományi Intézet, Budapest (Munkagazdaságtani Füzetek; 7.)

Koós B. (2013): A közszolgáltatás-szervezés és a költséghatékonysági kényszer a kistelepülések körében. In: Kovács K., Váradi M. (szerk.): Hátrányban vidéken. Argumentum, Budapest, 248-274.

Kovách I. (2007): A múlt és jelen vidékképe. Bevezetés. In: Kovách I. (szerk.): Vidék- és falukép a változó idóben. Argumentum Kiadó, Budapest, 7-11.

Kovách I. (2012): The countryside on the turn of the new millennium. Changes in the structure and power relations of rural societies in present-day Hungary. Argumentum, Budapest

Kovács K. (2010): Vidéki változások a rendszerváltozás után. In Barta Gy., Beluszky P., Földi Zs., Kovács K. (szerk): A területi kutatások csomópontjai. MTA RKK, Pécs, 73-104.

Kuus, M. (2013): Places of lower rank: Margins in conversations. Political Geography, 37., 30-32. http://doi.org/z7g

Ladányi J., Szelényi I. (2004): A kirekesztettség változó formái. Napvilág Kiadó, Budapest 
Leimgruber, W. (2007): Geographical marginality - past and new challenges. In: Jones, G., Leimgruber, W., Nel, E. (eds.): Issues in geographical marginality. Rhodes University, Grahamstown, 3-12.

Letenyei L. (2000): Innovációs láncok falun. Szociológiai Szemle, 4., 40-56.

Mansvelt, J. (2006): Geographies of consumption: citizenship, space and practice. Progress in Human Geography, 1., 105-117. http://doi.org/b2c6fj

Marini, M. B., Mooney, P. H. (2006): Rural economies. In: Cloke, P., Marsden, T., Mooney P. H. (eds.): Handbook of rural studies. SAGE, London, 91-103. http://doi.org/z7h

Massey, D. (2008): For space. SAGE, London

Megyesi B. (2007): A magyar lakosság vidékkel kapcsolatos attitűdjei. In: Kovách I. (szerk.): Vidékiek és városiak. A tudás- és imázshasználat hatásai a vidéki Magyarországon. L'Harmattan, MTA PTI, Budapest, 27-43.

Nagy, G. (2005): Changes in the position of Hungarian regions in the country's field of gravity. In: Barta, Gy., G. Fekete, É., Szörényiné Kukorelli, I., Timár, J. (eds.): Hungarian spaces and places: Patterns of transition. MTA RKK, Pécs, 124-142.

Pásztor, I. Z., Pénzes, J. (2012): Investigation of peripherisation in Northeastern-Hungary by spatial demographic and income tendencies with special attention to the Roma population. Eurolimes, 13., 149-165.

Pavlínek, P., Domanski, B., Guzik, R. (2009): Industrial upgrading through foreign direct investment in Central European automotive manufacturing. European Urban and Regional Studies, 1, 43-63. http://doi.org/dvq2q6

Pickles, J., Smith, A. (2011): De-localisation and persistence in the European clothing industry: The reconfiguration of trade and production networks. Regional Studies, 2., 167-185. http://doi.org/b7spmp

Sharp, J. (2011): Subaltern geopolitics: Introduction. Geoforum, 3., 271-273. http://doi.org/d6983j

Smith, J., Jehlicka, P. (2007): Stories around food, politics and change in Poland and the Czech Republic. Transactions of the Institute of British Geographers, 3., 395-410. http://doi.org/dw5m3s

Schmidt, M. (2007): The influence of scale on the basic dimensions and indicators of marginality. In: Jones, G., Leimgruber, W., Nel, E. (eds.): Issues in geographical marginality. Rhodes University, Grahamstown, 52-65.

Smith, N. (1996): The new urban frontier. Gentrification and the revanchist city. Routledge, London, New York

Stenning, A., Smith, A., Rochovská, A., Światek, D. (2011): Domesticating neoliberalism. spaces of economic practice and social reproduction in post-socialist cities. Wiley-Blackwell, Oxford

Szalai J. (2002): A társadalmi kirekesztődés egyes kérdései az ezredforduló Magyarországán. Szociológiai Szemle, 4., 34-50.

Timár J., Fabula Sz. (2013): Whose identity politics? Lessons for emerging critical disability geography in Hungary. Geographica Helvetica, 3., 171-179. http://doi.org/z7j

Timár, J., Nagy, E. (2012): Urban restructuring in the grip of capital and politics: Gentrification in East-Central Europe. In: Csapó T., Balogh A. (eds.): Development of the settlement network in the Central European countries: Past, present, and future. Springer Verlag, Heidelberg, Berlin, 121-135. http://doi.org/ch2f6x

Váradi, M. (2005): Increasingly fossilised labour market structures and strategies of livelihood: Chances of disadvantaged groups in the labour market. In: Barta, Gy., G. Fekete, É., Szörényiné Kukorelli, I., Timár, J. (eds.): Hungarian spaces and places: Patterns of transition. MTA RKK, Pécs, 289-306.

Virág T. (2010): Kirekesztve. Falusi gettók az ország peremén. Akadémiai Kiadó, Budapest

Wacquant, L. (2011): Lakóhely szerinti megbélyegzés a fejlett marginalitás korában. Fordulat, 13., 12-27.

Ward, P. M. (2004): From the marginality of the 1960s to the 'new poverty' of today. Latin American Research Review, 1., 183-187. http://doi.org/d6mz5w

Welch, J., Dear, M. (2005): Understanding homelessness: From global to local. In: Kleniewski, N. (eds.): Cities and society. Blackwell, Oxford, 147-167. http://doi.org/cgqp8n

Williams, C. C. (2005): Market delusions: rethinking the trajectories of post-socialist societies. Foresight, 3., 48-60. http://doi.org/dtds22 